\title{
Yield and Agronomic Performance of Selected Semi-dwarf Tef (Eragrostis tef (Zucc.) Trotter) Genotypes under Irrigation Farming System in Ethiopia
}

\author{
Tsion Fikre ${ }^{1, ~ *}$, Yazachew Genet ${ }^{1}$, Worku Kebede ${ }^{1}$, Kidist Tolossa ${ }^{1}$, Solomon Chanyalew ${ }^{1}$, \\ Mengistu Demissie $^{1}$, Kebebew Assefa ${ }^{1}$, Atinkut Fentahun ${ }^{2}$, Esuyawkal Demis ${ }^{3}$, Tadiyos Bayisa ${ }^{4}$, \\ Zerihun Tadele ${ }^{5}$ \\ ${ }^{1}$ Ethiopian Institutes of Agricultural Research, Debre Zeit Agricultural Research Center, Debre Zeit, Ethiopia \\ ${ }^{2}$ Amhara Regional Agricultural Research Institute, Adet Agricultural Research Center, Bahir Dar, Ethiopia \\ ${ }^{3}$ Ethiopian Institute of Agricultural Research, Mehoni Agricultural Research Center, Mehoni, Ethiopia \\ ${ }^{4}$ Ethiopian Institute of Agricultural Research, Werer Agricultural Research Center, Werer, Ethiopia \\ ${ }^{5}$ Institute of Plant Sciences, University of Bern, Bern, Switzerland
}

Email address:

tsifikre@yahoo.com (T. Fikre)

${ }^{*}$ Corresponding author

\section{To cite this article:}

Tsion Fikre, Yazachew Genet, Worku Kebede, Kidist Tolossa, Solomon Chanyalew, Mengistu Demissie, Kebebew Assefa, Atinkut Fentahun, Esuyawkal Demis, Tadiyos Bayisa, Zerihun Tadele. Yield and Agronomic Performance of Selected Semi-dwarf Tef (Eragrostis tef (Zucc.) Trotter) Genotypes under Irrigation Farming System in Ethiopia. American Journal of Plant Biology. Vol. 5, No. 4, 2020, pp. 110-119. doi: 10.11648/j.ajpb.20200504.16

Received: October 27, 2020; Accepted: November 18, 2020; Published: November 27, 2020

\begin{abstract}
Tef is a foremost staple cereal crop with considerable role in the domestic GDP of Ethiopia. In diverse parts of Ethiopia, declining levels and high variability of rainfall is among the main causes for low crop productivity. Therefore, the study was designed to assess, pinpoint and recommend promising tef breeding lines suitable for irrigation farming conditions in the semi-arid, temperate and cool sub-humid agro-ecologies of Ethiopia. The experimental plant materials comprised fortynine tef genotypes including forty seven recombinant inbred lines (RILs) and two standard checks varieties Quncho and Boset. The forty-seven RILs were out-sourced from three simple crosses of four parental lines. The field experiment was conducted using $7 \times 7$ simple lattice designs at three locations (Mehoni, Koga and Werer) during 2016 and 2017. Data were taken on plot and individual plant basis on nine pheno-agro-morphological characters including days to heading and to maturity, grain filling period, plant height, culm length, panicle length, above-ground shoot biomass, grain yield and harvest index. The three locations displayed highly significant $(\mathrm{P}<0.001)$ differences for a number of traits. However, panicle length did not show marked difference between locations. The cropping seasons has also showed highly significant $(\mathrm{P}<0.001)$ variation aside from plant height. Averaged over locations and seasons, differences among the genotypes were significant for all traits except days to maturity. The pooled result at the two locations (Mehoni and Koga) showed Kaye Murri X 3774-13 RIL 55 has the maximum yield of $3.1 \mathrm{t} \mathrm{ha}^{-1}$. Thus, it is suggested to use the selected genotype for the sites and similar agro-ecologies. The use of irrigation system showed merit of achieving maximum yield of $4.7 \mathrm{t} \mathrm{ha}^{-1}$ at Mehoni during 2016 (Kaye Murri X 3774-13 RIL 66), but this is not consistent over locations and years. Nowadays, straw also has comparable values to grain yield, hence, the highest aboveground shoot biomass yield and lowest harvest index were indicated by Kaye Murri X 3774-13 RIL 110. Consequently, it would be advisable to use both (Kaye Murri X 3774-13 RIL 66 and Kaye Murri X 3774-13 RIL 110) to further test in the breeding program.
\end{abstract}

Keywords: Boset, Irrigation, Quncho, RILs, Semi-dwarf, Tef, Yield 


\section{Introduction}

Tef (Eragrostis tef (Zucc.) Trotter belongs to the grass family, Poaceae (formerly Gramineae), sub-family Chloridoidae (Eragrostoidae), tribe Eragrostidae, sub-tribe Eragrosteae, and genus Eragrostis. The genus Eragrostis comprises approximately 400 morphologically distinct species distributed throughout the subtropical and tropical regions of the world [13]. Eragrostis tef (Zucc.) Trotter is the sole species in the genus Eragrostis cultivated for human consumption [27]. Tef is an allotetraploid $(2 n=4 x=40)$ plant whose diploid progenitor (s) are not yet known. Five possible progenitors for this cereal were suggested, namely: Eragrostis pilosa (L.) [20, 34], Eragrostis aethiopica or Eragrostis pseudo-tef [40], Eragrostis macilenta [11] and Eragrostis longifolia [32]. Of these, the first two morphologically resemble tef more than the remaining three [12]. It is a $\mathrm{C} 4$ plant similar to most tropical grasses such as maize (Zea mays L.) and sorghum (Sorghum bicolor (L.) Moench), and these pathway permits efficient utilization of high solar heat.

Tef is the main staple cereal crop that plays a considerable role in the domestic GDP of Ethiopia. It is annually grown by over 6.7 million framers' households [14]. Based on the archeological evidences, its cultivation was found in Axum, Ethiopia dating back to $2700-2800$ B. C [15]. Since then, extensive tef husbandry is continued due to its agronomic and dietary qualities. The typical agronomic merits of the crop include broad and versatile agro-ecological adaptation under varied climatic, edaphic and socio-economic condition; tolerance to both drought and water-logging conditions; fitness for various cropping systems and crop rotation schemes; usefulness as a reliable and low-risk catch crop at times of failures of other long-season crops such as maize and sorghum due to drought or pests; and little vulnerability to epidemics of pests and diseases in its major growing regions [10]. Furthermore, tef is consumed as whole-grain and its most imperative relative virtues in terms of dietary qualities is that tef grain is gluten-free and contains all eight essential amino acids, as well as high contents of fiber, minerals, and vitamins [31]. It is also known as a highquality forage crop due, among others, to its high feed quality, crude protein content, fast growth rate, and its suitability for multiple harvests $[28,30]$.

Owning to its significant role and broad husbandry, however, productivity and research exertion is just a nascent. One of the main limiting factor for yield reduction in tef is moisture stress [5]. Approximately 25.5 to $51 \%$ grain yield reduction in tef has been reported due to low moisture stress $[1,36]$. In different parts of Ethiopia, declining levels and high variability of rainfall is among the main causes for low crop productivity [39]. Besides, the rainfall is seasonal and concentrated in only 3 months of the year from June to August. Accordingly, the major farming system of the country is rain-fed agriculture concentrated in the high-lands that appear to shoulder the responsibility of feeding the population beyond 73.9 million [18], and when it is coupled with uneven distribution of rainfall it becomes a risky enterprise [23]. While dryland areas of Ethiopia account for more than $66 \%$ of the total landmass, it, however, contributes only less than $30 \%$ to the country's total agricultural production [33]. To this fact, food insecurity has remained to be the major problem of great concern to the country. In order to assuage the food insecurity problem with its roots in the high population growth rate and low food production level mainly attributed to insufficient moisture, it is vital to bring large areas of the arid, semi-arid and sub-humid regions with uneven rainfall distribution to irrigation production and other appropriate technology interventions [43]. Tef is highly durable to various stresses and thrives in a variety of environments [26], and due to this it becomes a preferred crop for the aforementioned and other locations which have irregular rainfall distribution. The stages of growth at which tef encounters frequent moisture stress include the seedling, vegetative and reproductive stages; however, moisture stress occurring during the anthesis and grain filling stages is considered to be critical since moisture substantially reduces yield [37]. The huge amount of yield loss accounted by moisture stress during vegetative and anthesis stage of tef reaches up to $40 \%$ [7] and $77 \%$ [37].

One of the escape mechanisms for the recurrent moisture stress is using irrigation by diverting water onto fields if there is available groundwater or river nearby. Irrigation has a multi-faceted role in contributing towards food security, selfsufficiency, food production and exports [24]. It is reported that under rain-fed agriculture where tef is mainly produced the mean grain yield is $1.75 \mathrm{t} \mathrm{ha}^{-1}$ [14], while under irrigation it is $3.3 \mathrm{t} \mathrm{ha}^{-1}$ [41]. Although tef gives almost double yield under irrigation as compared to rain-fed, it is not commonly used in Ethiopia due to lack of effective technologies for irrigated agricultural system. Amongst these, lack of varieties suitable for irrigation is one problem that needs to be addressed. Currently, feeding of the ever-increasing population and meeting the huge market preference of tef has not at all been achieved by using rain-fed production system. As a result, the use of irrigation becomes compulsory. Due this fact, the National Tef Improvement Program has attempted to develop genotypes that are apt for irrigation condition considering the growing demand in very near future. Hence, the study was designed to assess, pinpoint and recommend promising tef breeding lines suitable for tef husbandry under irrigation farming conditions in the semiarid, temperate and cool sub-humid agro-ecologies of Ethiopia.

\section{Materials and Methods}

\subsection{Plant materials}

The experimental plant materials comprised forty-nine tef genotypes including forty seven recombinant inbred lines (RILs) and two standard check varieties, Quncho and Boset. The forty-seven RILs were out-sourced from three simple crosses of four selected parental lines. The aim of the 
hybridization work was to develop stable, high yielding, white seeded, and farmer- and consumer-preferred tef varieties for the high rainfall and moisture stress areas as well as for irrigated farming system. The three independent crosses made in 2011 were Kaye Murri X 3774-13 (twenty three genotypes), GA-10-3 X Kaye Murri (sixteen genotypes) and DZ-Cr-387 X GA-10-3 (eight genotypes). The parental line Kaye Murri which was a local cultivar recognized and labeled by [17]. The cultivar Kaye Murri used both as female and pollen parent was selected for its thick culm, very white seed color and vigorous growth habit. One of the other parental lines is the popular variety Quncho (DZ-Cr-387 RIL 355) [4] was used as a female parent due to its high yielding ability and wide adaptability. The remaining two parents were dwarf mutant tef lines, namely 3774-13 (Kegne) [25] and GA-10-3 (Kinde) (Tadele et al., unpublished). Both of these were identified at the University of Bern in Switzerland from the screening of 5000 mutagenized tef populations, and they were selected as a pollen and female parent due to their earliness and dwarf nature in relation to lodging tolerance. The hybridization and handling of segregant population were made at Debre Zeit Agricultural Research Center (DZARC) from where the National Tef Research Program is coordinated. From each of the simple crosses, 400 F2 seeds were taken advanced upto F8 using the single seed descent method (SSD). Eventually, the recombinant inbred lines were considerably reduced to few lines through modified bulk selection. Ultimately, tough selection focusing on standing ability and grain yield was done and the best performing lines at the eight filial generations was used for the study. The crossing combinations and names of recombinant inbred lines as well as control materials used in the study are shown on Table 1.

Table 1. List of forty-nine experimental tef genotypes.

\begin{tabular}{|c|c|c|c|c|c|}
\hline Code. & Parents & Lines & Code. & Parents & Lines \\
\hline 1 & Kaye Murri X 3774-13 & RIL-173 & 26 & GA-10-3 X Kaye Murri & RIL-275 \\
\hline 2 & Kaye Murri X 3774-13 & RIL-202 & 27 & GA-10-3 X Kaye Murri & RIL-192 \\
\hline 3 & Kaye Murri X 3774-13 & RIL-147 & 28 & GA-10-3 X Kaye Murri & RIL-171 \\
\hline 4 & Kaye Murri X 3774-13 & RIL-71 & 29 & GA-10-3 X Kaye Murri & RIL-257 \\
\hline 5 & Kaye Murri X 3774-13 & RIL-45 & 30 & GA-10-3 X Kaye Murri & RIL-261 \\
\hline 6 & Kaye Murri X 3774-13 & RIL-72 & 31 & GA-10-3 X Kaye Murri & RIL-186 \\
\hline 7 & Kaye Murri X 3774-13 & RIL-87 & 32 & GA-10-3 X Kaye Murri & RIL-273 \\
\hline 8 & Kaye Murri X 3774-13 & RIL-133 & 33 & GA-10-3 X Kaye Murri & RIL-248 \\
\hline 9 & Kaye Murri X 3774-13 & RIL-66 & 34 & GA-10-3 X Kaye Murri & RIL-241 \\
\hline 10 & Kaye Murri X 3774-13 & RIL-10 & 35 & GA-10-3 X Kaye Murri & RIL-196 \\
\hline 11 & Kaye Murri X 3774-13 & RIL-80 & 36 & GA-10-3 X Kaye Murri & RIL-9 \\
\hline 12 & Kaye Murri X 3774-13 & RIL-55 & 37 & GA-10-3 X Kaye Murri & RIL-12 \\
\hline 13 & Kaye Murri X 3774-13 & RIL-68 & 38 & GA-10-3 X Kaye Murri & RIL-146 \\
\hline 14 & Kaye Murri X 3774-13 & RIL-105 & 39 & GA-10-3 X Kaye Murri & RIL-52 \\
\hline 15 & Kaye Murri X 3774-13 & RIL-144 & 40 & GA-10-3 X Kaye Murri & RIL-263 \\
\hline 17 & Kaye Murri X 3774-13 & RIL-215 & 42 & DZ-Cr-387 X GA-10-3 & RIL-168 \\
\hline 18 & Kaye Murri X 3774-13 & RIL-220 & 43 & DZ-Cr-387 X GA-10-3 & RIL-217 \\
\hline 19 & Kaye Murri X3774-13 & RIL-110 & 44 & DZ-Cr-387 X GA-10-3 & RIL-181 \\
\hline 20 & Kaye Murri X3774-13 & RIL-218 & 45 & DZ-Cr-387 X GA-10-3 & RIL-193 \\
\hline 21 & Kaye Murri X3774-13 & RIL-136 & 46 & DZ-Cr-387 X GA-10-3 & RIL-156 \\
\hline 22 & Kaye Murri X 3774-13 & RIL-60 & 47 & DZ-Cr-387 X GA-10-3 & RIL-154 \\
\hline 23 & Kaye Murri X 3774-13 & RIL-58 & 48 & DZ-Cr-387 X GA-10-3 & RIL-212 \\
\hline 24 & DZ-Cr-387 & Quncho & 49 & DZ-Cr-387 X GA-10-3 & RIL -72 \\
\hline 25 & DZ-Cr-409 & Boset & & & \\
\hline
\end{tabular}

\subsection{Description of the Study Sites and Season}

The experiment was conducted at two locations (Mehoni and Koga) for two consecutive years of 2016 and 2017, and at Werer in the year 2017 under irrigation. The locations have different contrasting features. Mehoni is located at Raya Valley (Fachagama) district in Southern Zone of Tigray
Regional State, northern Ethiopia, Werer is also situated in the middle of Awash Valley, $50 \mathrm{~km}$ north-east of the town of Awash of the Afar Region, and Koga is placed in the upper Blue Nile Basin under Mecha district in the West Gojam Zone, south of the Amhara Region. The detail description of the test locations presented on Table 2 .

Table 2. Geographical coordinates, weather data and soil type of the test locations.

\begin{tabular}{llll}
\hline \multirow{2}{*}{ Description of parameter } & \multicolumn{2}{c}{ Experimental locations } \\
\cline { 2 - 4 } & Koga & Mehoni (Fachagama) & Werer \\
\hline Distance from the capital (Km) & 543 & 678 & 280 \\
Latitude (N) & $11^{\circ} 25^{\prime} 20^{\prime \prime}$ & $12^{\circ} 41^{\prime} 50^{\prime \prime}$ & $9^{\circ} 16^{\prime}$ \\
Longitude (E) & $37^{\circ} 10^{\prime} 20^{\prime \prime}$ & $39^{\circ} 42^{\prime} 08^{\prime \prime}$ & $40^{\circ} 9^{\prime}$ \\
\hline
\end{tabular}




\begin{tabular}{llll}
\hline \multirow{2}{*}{ Description of parameter } & \multicolumn{2}{c}{ Experimental locations } \\
\cline { 2 - 3 } & Koga & Mehoni (Fachagama) \\
\hline Altitude (m.a.s.l) & 1960 & 1574 & Werer \\
Rain fall (mm) & 1118 & $300-750$ & 750 \\
Soil texture and/or type & Nitisols & Clay loam & 590 \\
Soil pH & $5.09-5.30$ & $7.9-8.1$ & Fluvisol \\
Max. mean daily temperature $\left({ }^{\circ} \mathrm{C}\right)$ & 26.8 & 25 & $7.5-8.4$ \\
Min. mean daily temperature $\left({ }^{\circ} \mathrm{C}\right)$ & 9.7 & Hot semi-arid \\
Climate & Cool semi-humid & Hot semi-arid \\
\hline
\end{tabular}

Source: Modified and compiled from [16, 21, 38, 29, 6, 42].

\subsection{Experimental Design and Field Management}

The field experiment was carried out using $7 \times 7$ simple lattice design. Each plot $(2 \mathrm{~m} \times 1 \mathrm{~m})$ consisted of five rows of $2 \mathrm{~m}$ length with an inter-row spacing of $0.2 \mathrm{~m}$. The distances were $1 \mathrm{~m}$ both between plots and incomplete blocks, and $1.5 \mathrm{~m}$ between replications. The varieties were allotted to plots at random within each replication. As per the research recommendations of $15 \mathrm{~kg} \mathrm{ha}^{-1}, 3 \mathrm{~g} \mathrm{plot}^{-1}$ of seeds was hand broadcasted along the surface of each row. The experiment was planted at Koga, Mehoni and Werer at different times (Table 3). Fertilizers used were $40 \mathrm{~kg} \mathrm{~N}$ and $60 \mathrm{~kg} \mathrm{P}_{2} \mathrm{O}_{5}$ per hectare for light soil, and $60 \mathrm{~kg} \mathrm{~N}$ and $60 \mathrm{~kg} \mathrm{P}_{2} \mathrm{O}_{5}$ per hectare for black soil. DAP was applied all at planting, while urea was applied two weeks after sowing and top dressed at tillering stage. At Werer, irrigation water was applied at every ten days interval from the first initial stage to heading/flowering and after heading to maturity at eight days interval with furrow irrigation method. At Mehoni, irrigation water was provided using a groundwater resource with sprinkler irrigation system. Before sowing the soil was moist and the amount of water was measured using soil squeezing method to test soil moisture manually by hand. At Koga, irrigation was applied at every seven days interval during seedling stage and fourteen days interval after seedling stage through flood irrigation system.

Table 3. Planting time of the three locations in two successive years.

\begin{tabular}{llll}
\hline \multirow{2}{*}{ Locations } & \multicolumn{2}{l}{ Planting time } & \\
\cline { 2 - 4 } & $\mathbf{2 0 1 5}$ & $\mathbf{2 0 1 6}$ & $\mathbf{2 0 1 7}$ \\
\hline Werer & - & - & Beginning of February \\
Mehoni & - & Beginning of March & Beginning of March \\
Koga & End of December & Beginning of December & - \\
\hline
\end{tabular}

\subsection{Data Collection}

Data for nine quantitative pheno-agro-morphological characters were recorded on plot and individual plant basis. Of these, the six characters taken on plot basis were days to heading to maturity, grain filling period, aboveground shoot biomass yield, grain yield and harvest index. The remaining three characters were based on individual plant basis included plant height, panicle length and culm length.

\subsection{Data Analyses}

For each trait analysis of variance was made first for individual locations, and eventually upon getting positive results from tests of homogeneity of variances using the method F-max of [22], a combined analysis of variance was made across locations and over years. For all analyses of variance, the general linear model (PROC GLM) [19] was employed using SAS software version 9.00 [35]. After getting significant differences for traits, pair-wise mean comparison was done using Least Significant Difference (LSD) at 0.05 significance level.

\section{Results and Discussion}

\subsection{Effect of Location on the Performance of Tef Genotypes}

The three locations displayed highly significant $(\mathrm{P}<0.001)$ differences for a number of traits. However, panicle length did not show marked difference between locations (Table 5). Phenologic traits showed substantial effects of locations. On the average, Werer exhibited the earliest maturity date, while Koga scored the latest record (Table 4). Generally, the means of grain yield were highest at Mehoni and lowest at Werer (Figure 1). As grain yield was also better at Koga than Werer, this may imply that late phenology may be more important (within a limit) for grain yield increment as suggested that long duration plants were more vigorous $[8,9]$. Hence, selection for grain yield in the set of tef genotypes is manifested by relatively long period for heading and grain filling period with short maturity time. This scenario would be practical under optimum environments since in stressed environments short grain filling time is likely to escape the water stress as the plant exerts more energy during this critical time. Likewise, it was also commending the possibility of using rapid maturity to escape the effects of drought [26]. 
Table 4. Mean and standard error (SE) of mean for nine traits of 49 tef genotypes at three locations.

\begin{tabular}{llll}
\hline \multirow{2}{*}{ Characters } & Mehoni & Koga & Werer \\
\cline { 2 - 4 } & Mean \pm SE & Mean \pm SE & Mean \pm SE \\
\hline Days to heading (days) & $57 \pm 0.55$ & $62 \pm 1.35$ & $36 \pm 0.72$ \\
Days to maturity (days) & $93 \pm 0.25$ & $104 \pm 1.32$ & $66 \pm 0.99$ \\
Grain filling period (days) & $36 \pm 0.45$ & $43 \pm 0.45$ & $30 \pm 1.19$ \\
Plant height (cm) & $88 \pm 0.51$ & $85 \pm 0.87$ & $82 \pm 1.17$ \\
Panicle length (cm) & $33 \pm 0.31$ & $33 \pm 0.41$ & $33 \pm 0.61$ \\
Culm length (cm) & $55 \pm 0.48$ & $52 \pm 0.58$ & $49 \pm 0.88$ \\
Aboveground shoot biomass yield (kg/ha) & $11300 \pm 230.43$ & $7469 \pm 193.45$ & $5251 \pm 155.03$ \\
Grain yield (kg/ha) & $2525 \pm 76.37$ & $2243 \pm 52.18$ & $952 \pm 40.60$ \\
Harvest index (\%) & $22 \pm 0.45$ & $31 \pm 0.52$ & $18 \pm 0.65$ \\
\hline
\end{tabular}

Table 5. Mean squares from the combined analysis of variance on nine characters of 49 tef genotypes tested in 2016 and 2017 under irrigations at two locations (Mehoni and Koga).

\begin{tabular}{|c|c|c|c|c|c|c|c|c|}
\hline \multirow{2}{*}{ Characters } & \multicolumn{7}{|c|}{ Mean square } & \multirow{2}{*}{ CV $(\%)$} \\
\hline & G (48) & L (1) & Y (1) & G x L (48) & Gx Y (48) & Lx Y (1) & Gx Lx Y (48) & \\
\hline Days to heading (days) & $*$ & $* * *$ & $* * *$ & ns & ns & $* * *$ & Ns & 10.3 \\
\hline Days to maturity (days) & ns & $* * *$ & $* * *$ & ns & ns & $* * *$ & Ns & 7.4 \\
\hline Grain filling period (days) & $* * *$ & $* * *$ & $* * *$ & ns & ns & $* * *$ & $*$ & 11.7 \\
\hline Plant height (cm) & $* * *$ & $* * *$ & ns & $* * *$ & ns & ns & Ns & 9.8 \\
\hline Panicle length $(\mathrm{cm})$ & $* * *$ & ns & $* * *$ & $* * *$ & ns & $*$ & Ns & 12.7 \\
\hline Culm length (cm) & $*$ & $* * *$ & $* * *$ & $* * *$ & $* *$ & ns & $* *$ & 11.7 \\
\hline Aboveground shoot biomass yield (kg/ha) & $* * *$ & $* * *$ & $* * *$ & $* * *$ & $* * *$ & $* * *$ & $* * *$ & 18.9 \\
\hline Grain yield (kg/ha) & $* * *$ & $* * *$ & $* * *$ & $* * *$ & $* * *$ & $* * *$ & $* * *$ & 17.1 \\
\hline Harvest index $(\%)$ & $* *$ & $* * *$ & $* * *$ & $* *$ & $* * *$ & $* * *$ & $* *$ & 20.1 \\
\hline
\end{tabular}

$*, * *$ Significant at $\mathrm{p} \leq 0.05, \mathrm{p} \leq 0.01$ and $\mathrm{p} \leq 0.001$ probability level respectively and ${ }^{\mathrm{ns}}$ non-significant. ${ }^{\beta}$ figures in parenthesis indicate degrees of freedom.

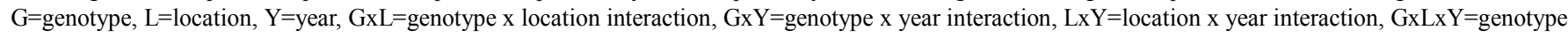
$\mathrm{x}$ location $\mathrm{x}$ year interaction, $\mathrm{CV}=$ coefficient of variation.

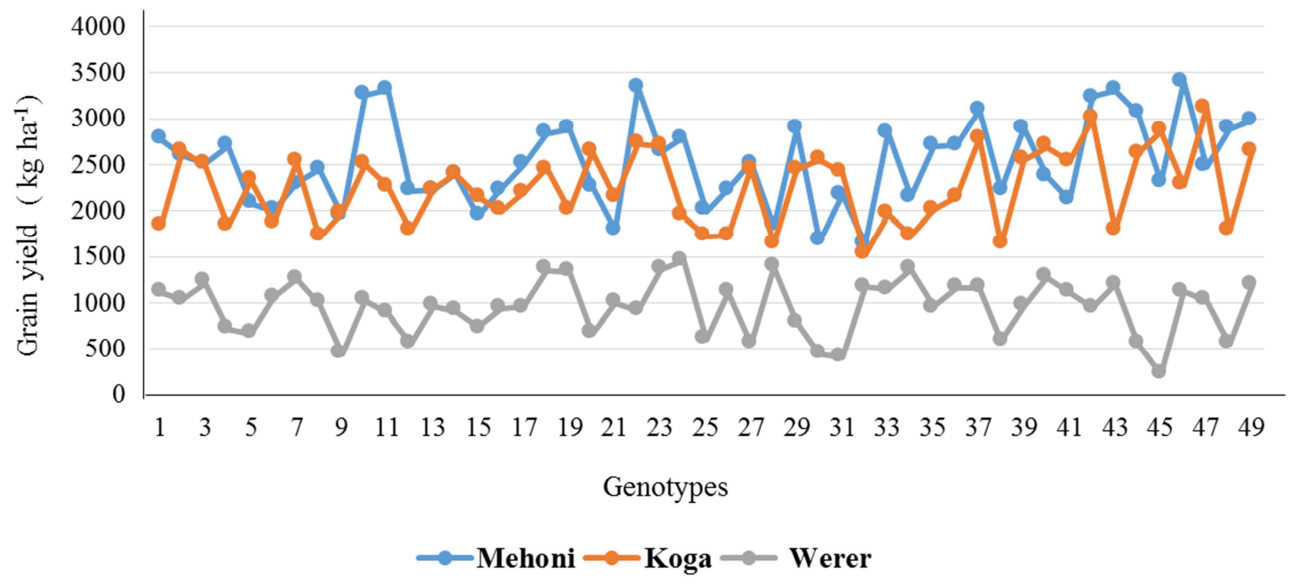

Figure 1. Performances in grain yield of the 49 tef genotypes across three test locations.

\subsection{Interaction Effect on the Performance of Tef Genotypes}

The interaction between genotype by year, location by year and genotype by location by year were significant $(\mathrm{P}<0.001)$ for aboveground shoot biomass yield, grain yield and harvest index, nevertheless, plant height revealed non-significant difference. The cropping seasons has also showed highly significant $(\mathrm{P}<0.001)$ variation except plant height. Genotype by location interaction indicated significant $(\mathrm{P}<0.001)$ interaction for the studied traits but phenologic characters (Table 5). When significant, genotype by location interaction effects were mostly "cross-over" type as manifested by changes in rank order of the genotypes in terms of mean grain yield (Table 6). This indicates that the three locations have diverse effects on some of the traits and that better genotypes at one location may not also be better performing at another. Such interaction depicted the differential performance of the genotypes that testing the genotypes across location were apt in order to pinout the best parental lines at the respective location and to identify trait performance in relation to location effect. This result is also anticipated due to the presence of four distinct parental lines in making the three independent crosses.

\subsection{Genotype Performance}

The field performance of the test tef genotypes under irrigation situation were commendable and encouraged the production potential of tef besides rain-fed farming (Figure 2 
and 3). The difference among the genotypes were highly significant $(\mathrm{P}<0.01)$ for grain filling period, plant height, panicle length, aboveground shoot biomass and grain yield, harvest index and significant for culm length and days to heading (Table 5). Among the nine traits assessed, only days to maturity failed to show significant genotype variation. Compared to similar irrigation experiments, the present findings were in contrast with the results of [16] who found that tef genotype effects were significant on days to maturity but not on plant height, while [2] reported also that days to maturity was significant. This discrepancy may be due to the variation in the experimental locations and genotypes. The comparison of the RILs with the standard checks Boset and Quncho variety showed the excelling grain yield performances of some RILs (Table 6).

At Mehoni, Kaye Murri X 3774-13 RIL72 gave superior grain yield of $3.4 \mathrm{t} \mathrm{ha}^{-1}$ which has $22.5 \%$ and $13.8 \%$ yield advantage over Boset and Quncho, respectively. At Koga, Kaye Murri X 3774-13 RIL 80 showed the greatest yield of $3.1 \mathrm{t} \mathrm{ha}^{-1}$ having $70.2 \%$ and $17.8 \%$ yield increment over Boset and Quncho, respectively. At Werer, the maximum grain yield of $1.45 \mathrm{t} \mathrm{ha}^{-1}$ obtained from GA-10-3 X Kaye Murri RIL 273, which out-yielded Boset and Quncho by $31.4 \%$ and 23\%, respectively. Averaged over the two locations (Mehoni and Koga), Kaye Murri X 3774-13 RIL 55 gave the maximum yield of $3.1 \mathrm{t} \mathrm{ha}^{-1}$. However, there was no single genotype exhibiting consistent superiority for grain yield across locations. However, Kaye Murri X 3774-13 RIL 55 had better yield performance among the tested tef genotypes and it excelled the standard check varieties Boset significantly and Quncho only slightly. Consequently, it would be advisable to use this genotype as parental line for future breeding work under irrigation condition for cool semi-humid and hot semiarid climate with the altitude 1574 m.a.s.l and above. For the hot semi-arid climate with range of the elevation from 750 m.a.s.l and rainfall 590 mm, GA-10-3 X Kaye Murri RIL 273 is apt. On the contrary, the low yielding genotypes were Kaye Murri X 3774-13 RIL 7 (1.674 $\mathrm{tha}^{-1}$ ) at Mehoni, Kaye Murri X 3774-13 RIL 105 (1.523 $\mathrm{t} \mathrm{ha}^{-1}$ ) at Koga, and Kaye Murri X
3774-13 RIL $71\left(0.214 \mathrm{tha}^{-1}\right)$ at Werer. This showed that the lowest yield at Mehoni and Koga is the highest at Werer. The lowest yield at Werer may be due to environmental factor that hinders the genotype performance. Werer is one of the nontraditional tef growing areas and average grain yield was about $0.8 \mathrm{t} \mathrm{ha}^{-1}$ (personal communication). Hence, even the mean of $0.95 \mathrm{t} \mathrm{ha}^{-1}$ is better and the record of $1.45 \mathrm{t} \mathrm{ha}^{-1}$ is much superior. The major constraints at this site are high temperature and bird damage, and it is advisable to identify the proper sowing time to minimize the heat stress at the time of anthesis along with further screening efforts to identify relatively heat tolerant genotypes suitable for the area.

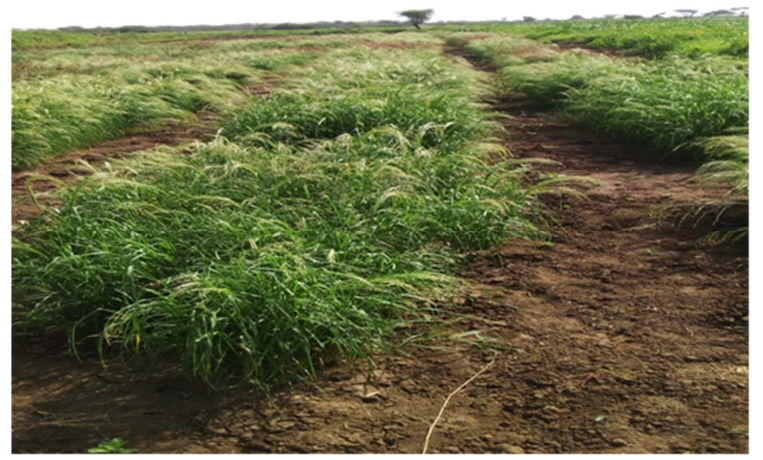

Figure 2. Field performance of semi-dwarf tef genotypes at Mehoni (Fachagama) station (Photo: Esuyawkal Demis).

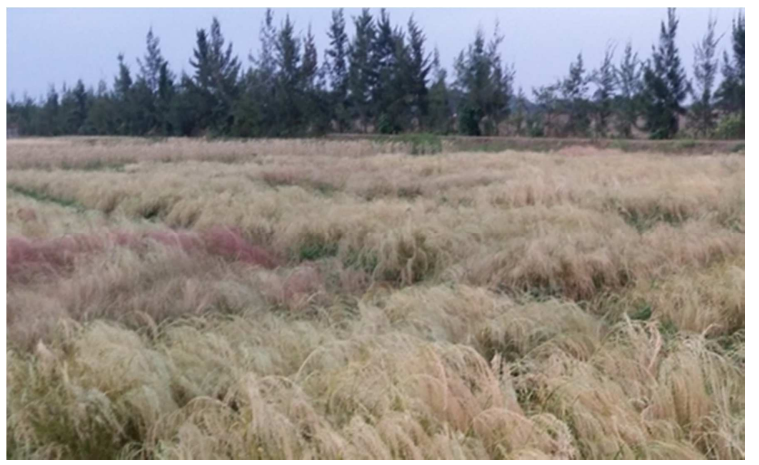

Figure 3. Field performance of semi-dwarf tef genotypes at Koga station. (Photo: Tsion Fikre in 25 April, 2017).

Table 6. Mean grain yield of 49 tef genotypes tested at three locations and combined over two years (2016 and 2017) at two locations (Mehoni and Koga) and a year (Werer, 2017) under irrigation condition.

\begin{tabular}{|c|c|c|c|c|}
\hline \multirow{3}{*}{ Genotypes } & \multicolumn{3}{|c|}{ Grain yield $\left(\mathrm{kg} \mathrm{ha}^{-1}\right)$} & \multirow{3}{*}{ Combined at two locations: Mehoni and Koga } \\
\hline & \multicolumn{3}{|c|}{ Locations } & \\
\hline & Mehoni & Koga & Werer & \\
\hline Boset & 2776 & 1830 & 1107 & 2303 \\
\hline DZ-Cr-387 X GA-10-3 RIL-154 & 2597 & 2648 & 1034 & 2622 \\
\hline DZ-Cr-387 X GA-10-3 RIL-156 & 2515 & 2491 & 1215 & 2503 \\
\hline DZ-Cr-387 X GA-10-3 RIL-181 & 2692 & 1826 & 713 & 2259 \\
\hline DZ-Cr-387 X GA-10-3 RIL-193 & 2083 & 2331 & 661 & 2207 \\
\hline DZ-Cr-387 X GA-10-3 RIL-217 & 2295 & 2521 & 1260 & 2408 \\
\hline DZ-Cr-387 X GA-10-3 RIL-72 & 2451 & 1712 & 991 & 2081 \\
\hline DZ-Cr-387 X GA-10-3 RIL-168 & 1947 & 1984 & 438 & 1966 \\
\hline GA-10-3 X Kaye Murri RIL-143 & 3259 & 2493 & 1030 & 2876 \\
\hline GA-10-3 X Kaye Murri RIL-186 & 3314 & 2263 & 888 & 2788 \\
\hline GA-10-3 X Kaye Murri RIL-196 & 2217 & 1784 & 558 & 2000 \\
\hline GA-10-3 X Kaye Murri RIL-257 & 2229 & 2234 & 963 & 2231 \\
\hline
\end{tabular}




\begin{tabular}{|c|c|c|c|c|}
\hline \multirow{3}{*}{ Genotypes } & \multicolumn{3}{|c|}{ Grain yield $\left(\mathrm{kg} \mathrm{ha}^{-1}\right)$} & \multirow{3}{*}{ Combined at two locations: Mehoni and Koga } \\
\hline & \multicolumn{3}{|c|}{ Locations } & \\
\hline & Mehoni & Koga & Werer & \\
\hline GA-10-3 X Kaye Murri RIL-146 & 1942 & 2155 & 734 & 2049 \\
\hline GA-10-3 X Kaye Murri RIL-52 & 2237 & 1996 & 941 & 2117 \\
\hline GA-10-3 X Kaye Murri RIL-12 & 2495 & 2196 & 959 & 2345 \\
\hline GA-10-3 X Kaye Murri RIL-9 & 2830 & 2460 & 1352 & 2645 \\
\hline GA-10-3 X Kaye Murri RIL-171 & 2880 & 1997 & 1333 & 2439 \\
\hline GA-10-3 X Kaye Murri RIL-192 & 2260 & 2640 & 664 & 2450 \\
\hline GA-10-3 X Kaye Murri RIL-241 & 1790 & 2136 & 998 & 1963 \\
\hline GA-10-3 X Kaye Murri RIL-248 & 3340 & 2727 & 909 & 3033 \\
\hline GA-10-3 X Kaye Murri RIL-261 & 2637 & 2696 & 1360 & 2666 \\
\hline GA-10-3 X Kaye Murri RIL-273 & 2796 & 1936 & 1455 & 2366 \\
\hline GA-10-3 X Kaye Murri RIL-275 & 1991 & 1715 & 606 & 1853 \\
\hline Kaye Murri X 3774-13 RIL-58 & 2239 & 1728 & 1113 & 1984 \\
\hline Kaye Murri X 3774-13 RIL-60 & 2518 & 2456 & 554 & 2487 \\
\hline Kaye Murri X 3774-13 RIL-215 & 1832 & 1650 & 1378 & 1741 \\
\hline Kaye Murri X 3774-13 RIL-220 & 2886 & 2455 & 790 & 2671 \\
\hline Kaye Murri X 3774-13 RIL-7 & 1674 & 2553 & 441 & 2113 \\
\hline Kaye Murri X 3774-13 RIL-10 & 2171 & 2410 & 411 & 2290 \\
\hline Kaye Murri X 3774-13 RIL-105 & 1648 & 1523 & 1178 & 1585 \\
\hline Kaye Murri X 3774-13 RIL-110 & 2851 & 1966 & 1143 & 2408 \\
\hline Kaye Murri X 3774-13 RIL-133 & 2150 & 1728 & 1354 & 1939 \\
\hline Kaye Murri X 3774-13 RIL-136 & 2697 & 2014 & 959 & 2355 \\
\hline Kaye Murri X 3774-13 RIL-144 & 2705 & 2147 & 1155 & 2426 \\
\hline Kaye Murri X 3774-13 RIL-147 & 3098 & 2782 & 1162 & 2940 \\
\hline Kaye Murri X 3774-13 RIL-173 & 2231 & 1632 & 590 & 1931 \\
\hline Kaye Murri X 3774-13 RIL-202 & 2899 & 2549 & 966 & 2724 \\
\hline Kaye Murri X 3774-13 RIL-218 & 2378 & 2690 & 1272 & 2534 \\
\hline Kaye Murri X 3774-13 RIL-45 & 2114 & 2535 & 1115 & 2324 \\
\hline Kaye Murri X 3774-13 RIL-55 & 3239 & 3002 & 944 & 3121 \\
\hline Kaye Murri X 3774-13 RIL-66 & 3300 & 1789 & 1197 & 2543 \\
\hline Kaye Murri X 3774-13 RIL-68 & 3053 & 2623 & 558 & 2838 \\
\hline Kaye Murri X 3774-13 RIL-71 & 2307 & 2855 & 214 & 2581 \\
\hline Kaye Murri X 3774-13 RIL-72 & 3400 & 2276 & 1125 & 2838 \\
\hline Kaye Murri X 3774-13 RIL-80 & 2476 & 3115 & 1022 & 2795 \\
\hline Kaye Murri X 3774-13 RIL-87 & 2884 & 1778 & 557 & 2331 \\
\hline Quncho & 2989 & 2644 & 1183 & 2816 \\
\hline Mean & 2525 & 2243 & 952 & 2384 \\
\hline $\operatorname{LSD}(0.05 \%)$ & 461.74 & 665.81 & 736.3 & 402.69 \\
\hline $\mathrm{R}^{2}$ & 0.95 & 0.79 & 0.58 & 0.90 \\
\hline CV $(\%)$ & 13.03 & 21.2 & 38.3 & 17.1 \\
\hline
\end{tabular}

\subsection{Range of Parameters}

Based on the average data over the two locations (Mehoni and Koga), wide ranges between the maximal and minimal mean values were observed for the traits evaluated (Table 7). The range of days to heading, days to maturity and grain filling period were 25-89, 72-128 and 18-66 days, respectively. Similarly, wide ranges were also noted for all the traits assessed.

The result of the current study have broader range for aboveground shoot biomass and grain yield that showed discrepancy from those reported based on review of various studies by [3] under rain-fed conditions. However, days to maturity, panicle length, plant height and culm length were within the ranges of values reported by [3]. Correspondingly, the minimum value for days to heading is in line with the result of [17]. The maximum value for days to heading and harvest index and the minimum value for grain filling period were noted in the present study. These differences might be because of the growing conditions and most of the previous study reports were based on rain-fed system. Nevertheless, the irrigation system brought the merit that the maximum yield achieved which is $4.7 \mathrm{t} \mathrm{ha}^{-1}$ at Mehoni during 2016 (Kaye Murri X 3774-13 RIL 66) and has $1.4 \mathrm{t} \mathrm{ha}^{-1}$ of yield increment than the study of [41], although this was not consistently the same over locations and years. In other way, it can be elucidated that irrigation is not always worth because the lowest grain and aboveground shoot biomass yield recorded here in the study is $0.287 \mathrm{tha}^{-1}$ and $0.5 \mathrm{t} \mathrm{ha}^{-1}$, respectively with the genotype of Kaye Murri X 3774-13 RIL 58. Thus, using the right genotype at the right location plays a pivotal role for increasing production and productivity of tef. Nowadays, straw also has comparable economic value to the grain yield, and to this effect the highest aboveground shoot biomass yield and lowest harvest index were exhibited by Kaye Murri X 3774-13 RIL 110. 
Table 7. Minimum and maximum values, means and standard errors (SE) of means for nine traits of 49 tef genotypes averages over two locations and years at Koga and Mehoni.

\begin{tabular}{|c|c|c|c|c|c|}
\hline Characters & Min value & Genotypes & Max value & Genotypes & Mean \pm SE \\
\hline Days to heading (days) & 25 & Code 20 & 89 & $\begin{array}{l}\text { Code } 11, \text { Code } 42, \text { Code } \\
39, \text { Code } 48\end{array}$ & $59 \pm 0.73$ \\
\hline Days to maturity (days) & 72 & Code 28 , Code 12 & 128 & Code 26 & $99 \pm 0.73$ \\
\hline Grain filling period (days) & 18 & Code 13 & 66 & Code 20 & $39 \pm 0.35$ \\
\hline Plant height (cm) & 52 & Code 26 & 113 & Code 48 & $87 \pm 0.51$ \\
\hline Panicle length $(\mathrm{cm})$ & 19 & Code 42 & 51 & Code 48 & $33 \pm 0.26$ \\
\hline Culm length $(\mathrm{cm})$ & 28 & Code 26 & 72 & Code 42 & $53 \pm 0.39$ \\
\hline Aboveground shoot biomass yield $\left(\mathrm{kg} \mathrm{ha}^{-1}\right)$ & 500 & Code 23 & 24330 & Code 19 & $9385 \pm 178.77$ \\
\hline Grain yield (kg ha $\left.{ }^{-1}\right)$ & 287 & Code 23 & 4707 & Code 9 & $2384 \pm 46.73$ \\
\hline Harvest index (\%) & 8 & Code 19, Code 22, Code 1 & 57 & Code 23 & $26 \pm 0.41$ \\
\hline
\end{tabular}

\section{Conclusions and Recommendations}

From the study, we can conclude that yield and agronomic performance of the selected tef genotypes showed wide variation for the studied traits. As grain yield is the economic trait in tef yield improvement program the parental line Kaye Murri X 3774-13 RIL 55 gave the maximum of 3.1t ha ${ }^{-1}$ pooled across two locations and years (Mehoni and Koga) and at Werer the best performing line was GA-10-3 X Kaye Murri RIL 273. Therefore, it is recommended to use the selected genotypes for the experimental sites and related agro-ecologies. In addition, at Werer further screening is needed since the experiment was done for only one year due to the presence of the unpredicted rainfall during the flowering time that brings significant yield reduction. Kaye Murri X 3774-13 RIL 66 gave the highest grain yield from among the selected genotypes at Mehoni during 2016, but it did not show stable performance across the test locations and over years. Hence, it is recommended to use it for further test and then incorporation in the future breeding effort.

\section{Acknowledgements}

The authors are grateful for the financial support of EIAR-ATA sub-grant Tef Research Project which was funded by DANIDA through the Ethiopian Agricultural Transformation Agency (ATA). Much gratitude also goes to Syngenta Foundation for Sustainable Agriculture (SFSA) and University of Bern $\left(\mathrm{U}^{\mathrm{b}}\right)$ for the provision of semi-dwarf tef lines. Considerable indebtedness is also extended to tef research teams of Debre Zeit, Adet, Mehoni and Werer Agricultural Research Centers for the successful and efficacious implementation of the study.

\section{References}

[1] Admas, S. and Belay, G. (2011). Drought-resistance traits variability in Eragrostis tef $X$ Eragrostis pilosa recombinant inbred lines. Afr. J. Agri. Res. 6: 3755-3761.

[2] Asaye Birhanu, Yismaw Degenet \& Zeyinu Tahir (2020) Yield and agronomic performance of released Tef [Eragrostis tef (Zucc.) Trotter] varieties under irrigation at Dembia, Northweastrn, Ethiopia, Cogent Food \& Agriculture 6: 1, 1762979.
[3] Assefa K, Ketema S, Tefera H, Hundera F and Kefyalew T (2001c). Genetic diversity for agronomic traits in tef. In: Hailu Tefera, Getachew Belay and Sorrells M. (eds.), Narrowing the Rift: Tef Research and Development, Proceedings of the International Workshop on Tef Genetics and Improvement, 16-19 October 2000, Debre Zeit, Ethiopia. pp. 33-48.

[4] Assefa K, S Aliye, G Belay, G Metaferia, H Tefera, ME Sorrells (2011a) Quncho: the first popular tef variety in Ethiopia. International J. of Agricultural Sustainability 9: 2534.

[5] Assefa K, JK Yu, M Zeid, G Belay, H Tefera and ME Sorrells (2011b) Breeding tef [Eragrostis tef (Zucc.) Trotter]: conventional and molecular approaches. Plant Breeding 130: $1-9$.

[6] Atakltie Abebe, Amare Tsige, Mulugeta Work and Alebachew Enyew. (2020) Optimizing irrigation frequency and amount on yield and water productivity of snap bean (Phaseolus Vulgaris L.) in NW Amhara, Ethiopia: A case study in Koga and Ribb irrigation scheme, Cogent Food \& Agriculture 6: 1 .

[7] Ayele M. (1993) Use of excised-leaf water content in breeding tef (Eragrostis tef (Zucc.) trotter). For Moisture Stress Areas. Acta Agronomica Hungarica 42: 261-266.

[8] Chanyalew S., Tefera H., Zelleke H., and Singh H. (2006). Correlation and path coefficient analysis of yield related traits in recombinant inbred lines of tef (Eragrostis tef). J. Genet. \& Breed. 60: 209-216.

[9] Chanyalew S., Tefera H and Singh H. (2009). Genetic variability, heritability, and trait relationships in recombinant inbred lines of tef [Eragrostis tef (Zucc.) Trotter]. Res. J. Agric. Biol. Sci. 5: 474-479.

[10] Chanyalew S., Ferede S., Damte T., Fikre F., Genet Y., Kebede W., Tolossa K., and Assefa K. (2019) Significance and prospects of an orphan crop tef. Planta, an International Journal of Biology 250: 753-767.

[11] Chevalier A. (1940) Révision des Eragrostis spontanés ou naturalisés en France. Bulletin de la Société Botanique de France Sériale B 87: 273-279.

[12] Clayton, W. D., Phillips, S. M. \& Renvoize, S. A. (1974). Gramineae (Part 2). In: Polhill, R. M. (ed.). Flora of Tropical East Africa. Crown Agents, London, UK. 449 p.

[13] Clayton WD, Vorontsova MS, Harman KT, Williamson H. (2016). GrassBase - the online world grass flora descriptions. Available at http://www.kew.org/data/grassesdb/sppindex.htm [accessed 07 September, 2019: 11: 35 GTM]. 
[14] CSA (2018). Central Statistical Agency, Agricultural Sample Survey 2017/18 (2010 E. C.), Volume I. Report on Area and Production of Major Crops (Private Peasant Holdings, Meher Season). Statistical Bulletin 586. Addis Ababa, Ethiopia.

[15] D'Andrea, A. C. (2008). Tef (Eragrostis tef) in ancient agricultural systems of highland Ethiopia. Econ. Bot. 62: 547566.

[16] Degife G, E Demis and G Haftu (2019). Screening of tef [Eragrostis tef (Zucc.) trotter] genotypes under irrigation at Raya Valley, Northern, Ethiopia. Inter J Agri Biosci. 8 (1): 50-55.

[17] Ebba, T. (1975). Tef (Eragrostis tef) Cultivars: Morphology and Classification. Part II. Exp. Station. Bull. No. 66. Addis Ababa: Addis Ababa Univ., College of Agriculture, Dire Dawa, Ethiopia.

[18] FDRE-PCC (Federal Democratic Republic of Ethiopia Population Census Commission), (2007). Summary and Statistical Report of the 2007 Population and Housing Census. Addis Ababa, Ethiopia.

[19] Gomez, K. A., and A. A. Gomez. (1984). Statistical Procedures for Agricultural Research. $2^{\text {nd }}$ ed., John Wiley and Sons. Inc., New York, USA.

[20] Hackel, E. (1890). The True Grasses. Henry Holt and Company, New York, USA. 228 p.

[21] Haileslassie G, Haile A, Wakuma B, Kedir J, (2015). Performance evaluation of hot pepper (Capsicum annum L.) varieties for productivity under irrigation at Raya Valley, Northern, Ethiopia. Basic Res. Journal Agri. Sci. Revolution 4: 211-216.

[22] Hartley HO (1950). The maximum F-ratio as a short cut test for heterogeneity of variances. Biometrika 37: 308-312.

[23] Hilemicael K and Alamirew T. (2017). Water productivity of tef under semi-arid climates. J. of Environment and Earth Sci. $7: 5$

[24] Hussain I, Hanjra MA (2004) Irrigation and poverty alleviation: review of the empirical evidence. Irrig Drain. 53 (1): $1-15$.

[25] Jost M, K Esfeld, A Burian, G Cannarozzi, S Chanyalew, C Kuhlemeier, K Assefa, Z Tadele. (2015). Semi-dwarfism and lodging tolerance in tef (Eragrostis tef) is linked to a mutation in the alpha-Tubulin 1 gene. Journal of Experimental Botany 66: 933-944.

[26] Ketema, S. (1993). Tef (Eragrostis tef): Breeding, Genetic Resources, Agronomy, Utilization and Role in Ethiopian Agriculture; Institute of Agricultural Research: Addis Ababa, Ethiopia.

[27] Ketema, S. (1997). Eragrostis tef (Zucc.) Trotter: Promoting the Conservation and Use of Underutilized and Neglected Crops; Institute of Plant Genetics and Crop Plant Research, Gatersleben/International Plant Genetic Resources Institute: Rome, Italy, 1997; ISBN 9290433043.

[28] Matthew Davidson, J. (2018). Evaluating tef Grass as a Summer Forage; College of Agriculture Manhattan: Kansas, NY, USA.

[29] Mehari H and Hailu B. (2019). Groundwater Characterization of Raya Valley for Irrigation use: The case of Mehoni Agricultural Research Center/Fachagama Experimental Site, Northern Ethiopia. International J. of Novel Res. in Life Sci. 6 (5): 46-52.

[30] Miller, D. (2010). Tef Grass: Crop Overview and Forage Production Guide; Cal/West Seed Company: Woodland, CA, USA.

[31] NRC (1996). (National Research Council). Lost Crops of Africa: Volume I: Grains, 1st ed.; National Academies Press: Washington, DC, USA. ISBN 978-0-309-04990-0.

[32] Portères, R. (1958). Les appellations des céréales en Afrique. Journal d'Agriculture Tropicale et de Botanique Appliquée 5: 454-486.

[33] Reddy, M. S. and K. Giorgis, (1994). Overview of dry land farming research of IAR: Objective and Focus. In: Reddy M. S. and K. Giorgis (eds). Development of technologies of the dry land farming areas of Ethiopia. Proc. of the First National Workshop on Dryland Farming Research in Ethiopia. 26-28 November. 1991. Nazareth, Ethiopia.

[34] Rozhevits, R. J. (1928). A bread plant of Abyssinia: E. tef (Zucc.) Trotter (in Russian). Bulletin of Applied Botany, Genetics and Plant Breeding (Trudy po Prikladnoj Botanike) 18: 389-403.

[35] SAS Institute (2002). SAS/STAT guide for personal computers, version 9.00 edition. SAS Institute Inc., Cary, NC.

[36] Shiferaw, W., A. Balcha, and H. Mohammed. (2012). Genetic variation for grain yield and yield related traits in tef [Eragrostis tef (Zucc.) Trotter] under moisture stress and nonstress environments. American Journal of Plant Sciences 3: 1041-1046.

[37] Takele, A. (2001). Canopy temperatures and excised leaf water loss of tef [Eragrostis tef (Zucc.) Trotter] cultivars under water deficit conditions at anthesis. Acta Agronomica $\begin{array}{llll}\text { Hungarica } & 49 & \text { (2), } & 109-117 .\end{array}$ org/10.1556/AAgr.49.2001.2.1.

[38] Tarekegne W, Mekbib F, and Dessalegn Y (2019). Performance and Participatory Variety Evaluation of Finger Millet [Eleusine coracana (L.) Gaertn] Varieties in West Gojam Zone, Northwest Ethiopia. East Afri. J. of Sci. 13 (1): 27-38.

[39] Tilahun K, (2006). Analysis of rainfall climate and evapotranspiration in arid and semi-arid regions of Ethiopia using data over the last half a century. Journal of Arid Environ. 64 (3): 474-487.

[40] Trotter, A. (1938). Di Attilio Zuccagni e della prima descrizione botanical del Tef etiopico. Annali della Facoltà di Scienze Agrarie della Università degli Studi di Napoli Portici 3 (9): 56-72.

[41] Yenesew, M. (2015). Agricultural Water Productivity Optimization for Irrigated Tef (Eragrostis tef) in Water Scarce Semi-Arid Region of Ethiopia, PhD Dissertation. Wageningen University, the Netherlands.

[42] Yeshaneh E, Wagner W, Michael Exner-Kittridge, Legesse D2 and Günter Blöschl. (2013). Identifying Land Use/Cover Dynamics in the Koga Catchment, Ethiopia, from Multi-Scale Data, and Implications for Environmental Change. ISPRS Int. J. Geo-Inf. 2: 302-323; doi: 10.3390/ijgi2020302. 
[43] Zenebe G., (2000). Effect of soil water deficit on growth, yield and yield components of cowpea genotypes, M. Sc. Thesis, Alemaya University, Ethiopia. 